\title{
REVIEWS.
}

\section{MORALITY AND REALITY.}

By E. Graham Howe, M.B., B.S.(Lond.), D.P.M. London. Gerald Howe, Ltd., 1934.

$$
\text { Price 6/-. }
$$

This monograph consists of five lectures delivered to the Home and School Council of Great Britain. The subject-matter is elaborated with originality, and taken as a whole it may perhaps be said that the main aim of the writer is to discuss the ethical implications of dynamic psychology. The sense in which the term "reality" is here used is "That which is now, which is not, as a whole, what I want". There is certainly something to be said for this quaint definition. The difficulty of life is a constant factor, and the assumption that an improvement in external conditions will ultimately make life "a bed of roses" is a pure fallacy; for new conditions always create new problems. Existence without stress and striving would obviously result in a state of psychic atrophy.

The writer defines Morality as a matter of form; it is behaviour about reality, an attitude about life, a code or system of rights and wrongs. As a psychopathologist he is naturally well acquainted with the all too frequent attempts to inhibit the psychic growth of children by forcing them to accept thoroughly unhealthy "moral" codes. Dr. Howe gives concrete instances of the baneful effects upon children resulting from the inhibitions imposed by stupid parents on their children, and we can only hope that modern psychological teaching has already done much to prevent the unwitting harm wrought by those who are responsible for the early training of the young.

Though Dr. Howe is by profession a psychotherapeutist, he reveals himself as a mystical philosopher as well. Like Jung, he attaches much importance to dreams, and, furthermore, suggests that death has importance in the span of life. He believes, indeed, that we shall never fully gain either true propontion or complete good humour, until we can see the whole, regarding death as part of life, and including waking and sleeping in the whole twenty-four hours of the day. This is an original contribution to an obscure subject written with sincerity and insight.

\section{THE NEW-BORN BABY.}

\section{By ErIC Pritchard. Henry Kempton, London. 1934. Price 4s. 6d.}

In this little volume, designed for the us of midwives and maternity nurses, a con? siderable amount of information on points of dress, environment, feeding and rearing of the new-born child is given in a terse and interesting fashion. Though we consider that much of the teaching regarding infantfeeding and the far-reaching effects of vitamins is unduly dogmatic and will not receive the general acceptance of his pædiatric colleagues, most of the information is just such as an intelligent midwife should possess.

\section{Miscellaneous.}

A NEW COMPANY.

As announced in our adventising section, a new company, Ciba Limited, 40, Southwark Street, London, S.E.1, Ciba (Telephone, Hop 1041; TeleLimited grams, Cibadrugs, Boroh, London) has taken over the Pharmaceutical Department of The Clayton Aniline Company Limited as Sole Concessionaires for the Ciba Brand Pharmaceutical Specialities, Coramine, Percaine, Dial, etc.
The Board of the new company consists of Dr. J. Brodbeck, President of the Society of Chemical Industry in Basle, Switzerland, Mr. A. E. Peak, Managing Director of The Clayton Aniline Co., Ltd., Manchester, Mr. J. J. Brodbeck, Director, Ciba Co., Inc., New York City, and Mr. T. F. M. Smart, O.B.E., late Manager of the Pharmaceutical Department of The Clayton Aniline Company. The change coincides with the jubilee of the Ciba firm in Basle. 